\title{
TROMBOEMBOLI PARU PADA ANAK
}

\author{
Diah Asri Wulandari, Heda Melinda D Nataprawira \\ Bagian IImu Kesehatan Anak \\ Fakultas Kedokteran Universitas Padjadjaran/Rumah Sakit Hasan Sadikin
}

\begin{abstract}
ABSTRAK
Tromboemboli paru dapat terjadi akibat adanya obstruksi pembuluh darah paru oleh trombi. Tromboemboli paru jarang didiagnosis dan dilaporkan pada anak, kebanyakan bahkan tidak terdiagnosis sampai setelah dilakukan otopsi. Penyakit yang pada dewasa meningkatkan risiko terjadinya tromboemboli juga berlaku untuk anak dan remaja. Penderita dengan tromboemboli paru biasanya mempunyai penyakit yang mendasari ataupun faktor pencetus, seperti imobilisasi, penggunaan vena sentral, penyakit jantung, trauma, operasi, infeksi, dehidrasi, keganasan, kelainan hematologi, serta kegemukan. Lokasi anatomis trombus vena pada anak berbeda dengan dewasa yaitu pada vena kranialis dan abdominalis, serta seringkali manifestasi klinisnya tidak jelas. Pada anak, tomboemboli paru harus dipertimbangkan pada beberapa keadaan, antara lain dalam mengevaluasi hipertensi paru yang tidak bisa diterangkan penyebabnya, insufisiensi respirasi, dan koagulasi intravaskular diseminata (KID). Pemeriksaan angiografi paru masih merupakan gold-standard untuk mendiagnosis tromboemboli paru dan merupakan pemeriksaan yang invasif. Pemeriksaan non-invasif multidetector helical/spiral computerized tomography scanning yang mempunyai sensitivitas dan spesifisitas tinggi merupakan teknik yang diharapkan dapat menggantikan pemeriksaan angiografi paru. Protokol pengobatan untuk anak masih belum berkembang, tetapi hingga saat ini antikoagulasi merupakan obat yang digunakan untuk mencegah perluasan bekuan dan rekurensi tromboemboli.
\end{abstract}

Kata kunci: Tromboemboli paru, angiografi paru, multidetector helical/spiral computerized tomography scanning, anak

\section{PULMONARY THROMBOEMBOLISM IN CHILDREN}

\begin{abstract}
Pulmonary thromboembolism could be happened because of pulmonary vessel obstruction by thrombi. Pulmonary thromboembolism is rarely diagnosed and reported in children, most of them are not diagnosed before autopsy was done. All adult diseases that increase the risk of thromboembolism occur in children and adolescent as well. Patients with pulmonary thromboembolism usually have serious underlying disorders or precipitating factors, such as immobility, central venous catheterization, heart disease, trauma, surgery, infection, dehydration, malignancies, hematologic disorders, and obesity. The anatomic site of venous thrombi in children differs from those in adult, which more likely to involve cranial or abdominal veins, and often asymptomatic. Pulmonary thromboembolism in children should be considered in the evaluation of unexplained pulmonary hypertension, respiratory insufficiency, and disseminated intravascular coagulation. Pulmonary angiography is considered to be the gold-standard for diagnosis of pulmonary thromboembolism, and it is an invasive procedure. Non-invasif procedure multidetector helical/spiral computerized tomography scanning with high sensitivity and specificity is promising technique may replace pulmonary angiography. Although definitive protocols for treatment of pulmonary thromboembolism in children have not been improved yet, but until now anticoagulation drugs is used to prevent clot extension and recurrent thromboembolim.
\end{abstract}

Key words: Pulmonary thromboembolism, pulmonary angiography, multidetector helical/spiral computerized tomography scanning, children

\footnotetext{
Alamat korespondensi:

dr. Diah Asri Wulandari, SpA

Subbagian Respirologi Bagian IImu Kesehatan Anak

Fakultas Kedokteran Universitas Padjadjaran/Rumah Sakit Hasan Sadikin

Jl. Pasteur no. 38 Bandung, Telp. 021-2035957,
}

Email: diahthyas@yahoo.com 


\section{PENDAHULUAN}

Emboli paru dapat disebabkan selain oleh udara, lemak, cairan amnion, tumor, atau benda asing, dan dapat disebabkan oleh trombus sehingga juga disebut sebagai tromboemboli paru (TP). Tromboemboli paru pada anak jarang terdiagnosis, sehingga tidak banyak pengalaman klinis dalam tatalaksananya. ${ }^{1-3}$ Pada orang dewasa tromboemboli paru merupakan salah satu penyebab kematian yang sering dilaporkan. Walaupun diperkirakan 3\% tromboemboli paru terjadi pada penderita usia di bawah 19 tahun, ${ }^{4}$ namun hampir tidak pernah atau jarang tromboemboli paru dilaporkan sebagai penyebab kematian pada anak (kurang dari 0,05\% pada laporan otopsi). Berdasarkan hasil pemeriksaan otopsi diperkirakan insidensnya mencapai 1 di antara 1.000 rawat inap anak dan dewasa. ${ }^{5}$

Walaupun diagnosis tromboemboli tidak dapat ditegakkan secara klinis karena tanda dan gejalanya tidak spesifik, namun tromboemboli paru harus dipertimbangkan dalam mengevaluasi beberapa keadaan antara lain hipertensi paru yang tidak dapat diterangkan penyebabnya (unexplained pulmonary hypertension). Dalam hal ini pada pemeriksaan ekokardiografi tidak ditemukan adanya pirau baik di jantung maupun di luar jantung, namun ventrikel kanan membesar dan terdapat peninggian tekanan arteri pulmonalis. Selain itu perlu dipertimbangkan apabila terdapat insufisiensi pernapasan dan koagulasi intravaskular diseminata (KID). ${ }^{3}$

Pemeriksaan angiografi paru adalah pemeriksaan diagnostik gold standard yang bersifat invasif yang berisiko besar, namun pada saat ini terdapat pemeriksaan non-invasif yaitu multidetector helical/spiral computerized tomography scanning untuk mendeteksi tromboemboli paru dapat menggantikan pemeriksaan yang invasif karena terbukti menunjukkan sensitivitas dan spesifisitas yang tinggi. ${ }^{4,5}$

\section{EPIDEMIOLOGI}

Tromboemboli paru jarang terjadi pada anak dan bayi. ${ }^{1}$ Sebuah penelitian prospektif di Kanada mengemukakan insidensi deep venous thrombosis (DVT)/TP sebanyak 5,3/10.000 dari anak yang dirawat di rumah sakit, atau 0,07/10.000 dari seluruh populasi anak. Suatu penelitian otopsi memperkirakan kejadian TP pada anak sebanyak $0,05-3 \%$. ${ }^{2}$ Penelitian serial otopsi yang lain menyatakan insidensi TP pada anak dan remaja yang dirawat di rumah sakit sebanyak $1 / 1.000$, namun hanya $25 \%$ yang menampilkan gejala klinis. ${ }^{3}$ Insidensi tertinggi TP pada anak terjadi pada usia $<1$ tahun dan pada usia 11-18 tahun. ${ }^{1}$ Walaupun frekuensi TP meningkat dengan bertambahnya usia, namun usia bukan merupakan faktor risiko independen. ${ }^{4,5}$
Di USA, TP merupakan penyebab kematian ketiga tersering, setidaknya 650.000 kasus terjadi tiap tahunnya dan penyebab utama kematian yang tidak terduga pada semua usia. ${ }^{4,6}$ Hasil otopsi, $60 \%$ penderita yang meninggal di rumah sakit menderita TP, namun yang tidak terdiagnosis sebanyak $70 \%$ kasus. ${ }^{4,7}$ Sekitar $10 \%$ penderita TP akut yang terdiagnosis meninggal dalam 60 menit pertama. ${ }^{1,7}$ Walaupun hampir sebanyak $3 \%$ TP fatal terjadi pada penderita usia <19 tahun, namun kematian mendadak karena TP masif sangat jarang $(<0,05 \%) .^{3}$ Pengobatan TP bertujuan untuk menurunkankan angka kematian dari 30\% menjadi kurang dari $10 \%{ }^{5,8}$ Penderita TP akut yang sembuh mempunyai risiko tinggi untuk mengalami TP berulang dan dapat terjadi hipertensi pulmonal serta korpulmonal kronik, keadaan tersebut terjadi sampai $70 \%{ }^{{ }^{4}}$

\section{FAKTOR RISIKO}

Sekitar $98 \%$ anak yang didiagnosis TP ditemukan adanya faktor risiko atau penyakit yang mendasarinya. ${ }^{2}$ Adapun faktor-faktor risiko terjadinya TP meliputi: ${ }^{4,5}$ 1) Keadaan primer (genetik): mutasi faktor $\mathrm{V}$, defisiensi antitrombin III, defisiensi protein $\mathrm{C}$ atau protein $\mathrm{S}$, defek fibrinolisis, golongan darah A, 2) Keadaan sekunder (didapat): tirah baring lama atau perjalanan yang lama, infark miokardium, kerusakan jaringan (operasi, patah tulang, luka bakar), keganasan, katup jantung buatan, disseminated intravascular coagulation (DIC), lupus antikoagulan, atrial fibrilasi, kardiomiopati dilatasi, tromboflebitis, sindrom neprotik, kateterisasi jantung, sickle cell anemia, pemasangan kateter vena sentral, kemoterapi, ventriculoatrial shunt pada hidrosefalus, sindrom Gulain-Barre, duchenne muscular dystrophy, kegemukan, gagal jantung kongestif, penyalahgunaan obat (iv), kolitis ulseratif, dan trombositosis, 3) Faktor risiko TP pada bayi baru lahir meliputi: trauma lahir, dehidrasi, sepsis, kelainan jantung bawaan, seperti patent ductus arteriosus (PDA), operasi jantung, faktor risiko pada ibu, seperti DM, hidramnion, dan toksemia. $^{3}$

Kejadian TP pada anak terutama terjadi pada: ${ }^{1}$ Abnormalitas koagulasi (sampai $70 \%$, terutama defisiensi protein $\mathrm{C}$ dan $\mathrm{S}$ ), dan penderita leukemia yang mendapat kemoterapi $(2,9 \%)$.

\section{PATOFISIOLOGI}

Pada keadaan normal, mikrotrombi (agregat kecil terdiri dari sel darah merah, trombosit, dan fibrin) terbentuk dan lisis secara berkesinambungan di dalam sistem sirkulasi vena. Keseimbangan tersebut menjaga hemostasis lokal 
dalam berespons terhadap injuri tanpa menyebabkan penyebaran trombi yang tidak terkontrol. Pada keadaan patologis, mikrotrombi dapat lolos dari sistem fibrinolitik yang normal dan kemudian menyebar. ${ }^{4}$ Trombosis pada vena dipicu oleh adanya venostasis, hiperkoagulabilitas, dan injuri dinding pembuluh darah. Ketiga keadaan ini dikenal sebagai Virchow triad. ${ }^{3-5,7}$

Tromboemboli paru terjadi bila penyebaran trombi ini menyebabkan obstruksi pembuluh darah paru. ${ }^{6,7}$ Lebih dari 90\% TP disebabkan trombi yang berasal dari vena dalam besar tungkai, terutama vena poplitea dan vena dalam di atasnya, namun TP dapat timbul karena trombi yang berasal dari vena kecil dalam di betis. ${ }^{4-6,9}$ Tromboemboli yang dilepaskan kedalam sirkulasi vena akan menyebar di kedua paru sebanyak $65 \%$, paru kanan sebesar $25 \%$, dan paru kiri sebanyak $10 \%$ kasus. Lobus paru bawah sebanyak 4 kali lebih sering terkena dari pada lobus atas. Tromboemboli besar terutama berada pada arteri pulmonal besar dan intermedia, hanya $\leq 35 \%$ mencapai arteri kecil. ${ }^{9}$ Setelah proses embolisasi, sistem fibrinolitik endogen akan mendegradasi trombi. Biasanya lisis trombi lengkap dalam beberapa hari sampai beberapa minggu pada keadaan tidak ada penyakit kardiopulmonal sebelumnya, namun gejala hipertensi paru dan gangguan fungsi paru dapat menetap. Walaupun begitu, tromboemboli masif dapat menyebabkan kematian dalam beberapa menit/jam sebelum infark terjadi. ${ }^{6,9}$ Pada keadaan yang jarang, tromboemboli dapat kembali terjadi setelah beberapa bulan/tahun, menyebabkan obstruksi arteri pulmonal progresif dengan hipertensi pulmonal kronik, dispnea, dan korpulmonale. ${ }^{9}$

Perubahan patofisiologi yang mengikuti TP meliputi ketidaksesuaian hemodinamik pulmonal dan pertukaran gas. Keadaan tersebut menyebabkan hipertensi pulmonal dengan gagal jantung kanan, syok, dispnea dengan takipnea dan hiperventilasi, hipoksemia arterial, serta infark paru. ${ }^{9}$

Hipertensi pulmonal disebabkan meningkatnya resistensi vaskular pulmonal, sehingga ventrikel kanan harus menghasilkan tekanan arteri pulmonal yang tinggi untuk mempertahankan curah jantung. Hipertensi pulmonal yang bermakna dapat terjadi setelah TP (>25 mm Hg mean pressure), biasanya terjadi pada paru yang sebelumnya sehat hanya bila $>30-50 \%$ dari cabang arteri pulmonalis yang tersumbat. Kejadian hipertensi pulmonal dapat meningkat dengan adanya penyakit kardiopulmonal sebelumnya seperti mitral stenosis atau chronic obstructive pulmonary disease (COPD). Tekanan sistolik arteri pulmonal dapat meningkat sampai $100 \mathrm{mmHg}$ pada TP akut, tapi dapat hanya mencapai $70-80 \mathrm{mmHg}$ jika terjadi regurgitasi trikuspid. Tekanan arteri pulmonal yang tinggi biasanya terjadi pada penderita yang $\begin{array}{rrr}\begin{array}{c}\text { sebelumnya } \\ \text { kardiopulmonal. }^{9}\end{array} & \begin{array}{r}\text { terdapat } \\ \text { Mekanisme }\end{array} & \begin{array}{r}\text { penyakit } \\ \text { utama }\end{array}\end{array}$ meningkatnya resistensi adalah obstruksi arteri pulmonal oleh trombi, yaitu dengan turunnya total area percabangan dari vascular bed pulmonal. Mekanisme kedua adalah terjadinya vasokonstriksi pulmonal. Vaso-konstriksi yang terjadi umumnya disebabkan hipoksemia karena pelepasan serotonin dari agregat trombosit pada trombi dan mungkin oleh substansi humoral lain termasuk prostaglandin., Jika resistensi pulmonal meningkat secara akut sebagai akibat dari ventrikel kanan tidak dapat menghasilkan tekanan yang cukup untuk mempertahankan curah jantung, terjadi hipotensi, serta peningkatan tekanan vena sentral dan atrium kanan. Syok kardiogenik pada penderita tanpa didahului penyakit kardiopulmonal hanya terjadi setelah TP masif. ${ }^{9}$

Takipnea seringkali disertai dispnea, dan hampir selalu terjadi setelah TP. Gejala ini timbul disebabkan rangsangan reseptor juxtacapillary pada membran kapiler alveolar oleh pembengkakan ruang interstitial alveolar. Keadaan tersebut meningkatkan aktivitas aferen refleks vagal, yang merangsang neuron respiratori medular. Sebagai akibatnya timbul hiperventilasi alveolar dengan manifestasi rendahnya $\mathrm{PCO}_{2}{ }^{9}$

Berkurangnya surfaktan alveolar dalam beberapa jam setelah TP disebabkan berkurangnya volume dan compliance paru. Berkurangnya volume paru sekunder terhadap atelektasis atau infark setelah TP dapat dilihat dengan adanya elevasi diafragma pada foto toraks. Dengan berkurangnya volume paru dan rendahnya $\mathrm{PCO}_{2}$ menyebabkan bronkokonstriksi, yang menyebabkan wheezing ekspirasi. Heparin tampaknya dapat mengurangi bronkokonstriksi dengan bukti meningkatnya kecepatan aliran ekspirasi maksimal. Walaupun perubahan pada paru biasanya bersifat sementara dan tampaknya tidak menimbulkan dispnea yang berkepanjangan, namun mungkin berhubungan dengan timbulnya hipoksemia arterial. $^{9}$

Hipoksemia arterial terjadi dengan berkurangnya saturasi $\mathrm{O}_{2}$ arteri $\left(\mathrm{SaO}_{2} \leq 94-85 \%\right)$, namun nilai $\mathrm{SaO}_{2}$ dapat normal. Hipoksemia berhubungan dengan right-to-left shunt pada area atelektasis. Atelektasis dapat dikoreksi secara partial dengan napas dalam atau dengan ventilator bertekanan positif. ${ }^{9}$

Ventilation/perfusion ( $\dot{\mathrm{V}} / \mathrm{Q})$ imbalance kemungkinan juga menyebabkan hipoksemia, mekanisme yang bertanggungjawab untuk $\dot{\mathrm{V}} / \dot{Q}$ imbalance dan atelektasis belum diketahui secara pasti. Pada TP masif, hipoksemia berat dapat terjadi karena tekanan atrium kanan meningkat sehingga terjadi aliran darah dari kanan ke kiri melalui foramen ovale. ${ }^{9}$

Infark paru (IP) adalah konsolidasi hemoragik (sering diikuti nekrosis) dari parenkim paru. Jika sirkulasi bronkial intak dan normal, IP 
Tabel Kriteria Wells dalam Prediksi Tromboemboli Secara Klinis

\begin{tabular}{lc}
\hline Tampilan klinis & Nilai \\
\hline - Gejala klinis DVT & 3 \\
- Diagnosis lain lebih tidak mungkin daripada TP & 3 \\
- Denyut nadi > 100 x/menit & 1,5 \\
- Imobilisasi atau operasi dalam 4 minggu yang lalu & 1,5 \\
- DVT/TP sebelumnya & 1,5 \\
- Batuk darah & 1 \\
- Keganasan & 1 \\
Nilai: >6: risiko tinggi $(78,4 \%)$ & \\
2- 6: risiko sedang $(27,8 \%)$ & \\
$<2:$ risiko rendah $(3,4 \%)$ &
\end{tabular}

dari arteri bronkial dapat melindungi jaringan paru meskipun terjadi hambatan arteri pulmonal. Namun pada penderita yang sebelumnya terjadi sirkulasi pulmonal abnormal, cenderung menjadi IP. Infark dapat sembuh dengan absorpsi dan fibrosis, serta meninggalkan linear scar, atau dapat diresorbsi secara sempurna pada infark inkomplit. $^{9}$

\section{GEJALA KLINIS}

Tromboemboli paru yang kecil pada umumnya bersifat asimtomatik. ${ }^{2,4}$ Gejala TP yang timbul pada penderita muda biasanya ringan. Tromboemboli paru harus dipertimbangkan pada anak dengan hipertensi pulmonal yang tidak dapat dijelaskan, adanya gangguan respirasi, disseminated intravascular coagulation (DIC), ${ }^{3}$ serta adanya riwayat keluarga dengan defek koagulasi atau meninggal karena kejadian trombosis pada usia $<50$ tahun. ${ }^{1}$

Gejala klinis yang yang dapat terjadi pada TP bervariasi, meliputi: nyeri dada, nyeri punggung, nyeri pundak, nyeri perut bagian atas, batuk darah, syncope, dispnea, wheezing, aritmia, atau gejala toraks lain yang tidak dapat dijelaskan. ${ }^{14,9}$ Berdasarkan The Prospective Investigation of Pulmonary Embolism Diagnosis (PIOPED), gejala yang paling sering ditemukan adalah dispnea $(73 \%)$, nyeri dada pleuritik $(66 \%)$, batuk $(37 \%)$, dan batuk darah $(13 \%)^{7}$ Tiga gejala dan tanda klasik TP berupa batuk darah, dispnea, dan nyeri dada. ${ }^{3,4}$ Namun, penderita yang meninggal karena TP masif, hanya $60 \%$ mempunyai gejala dispnea, $17 \%$ dengan gejala nyeri dada, dan $3 \%$ dengan batuk darah. ${ }^{4}$ Gejala nyeri dada pleuritik pada anak dengan TP dilaporkan sampai $84 \%$ dan batuk sebesar $50 \%,{ }^{2}$ serta hanya sejumlah kecil remaja dan dewasa muda dengan TP mempunyai gejala batuk darah. ${ }^{2,4}$ Sebanyak $21 \%$ penderita muda terbukti menderita TP, datang hanya dengan keluhan nyeri dada pleuritik. ${ }^{4}$

Pada fase awal, umumnya penderita TP tidak didapatkan pemeriksaan fisis yang abnormal. Takipnea merupakan pemeriksaan fisis yang paling sering ditemukan. Pemeriksaan fisis lain yang ditemukan meliputi: takikardia, takip-nea, dispnea, demam, flebitis, rales, wheezing, batuk darah, komponen pulmonal pada suara jantung kedua yang mengeras, peningkatan vena jugular, galop, edema, hipotensi, diapo-resis, dan pleuritic rub. ${ }^{2,7,8}$

Pada penderita dengan TP masif, pada pemeriksaan fisis ditemukan: ${ }^{4}$ takipnea $(96 \%)$, rales (58\%), bunyi jantung 2 mengeras (53\%), takikardia $(44 \%)$, panas badan $(43 \%)$, diaforesis $(36 \%)$, galop $(34 \%)$, tanda dan gejala tromboflebitis $(32 \%)$, edema tungkai bawah $(24 \%)$, murmur jantung $(23 \%)$, dan sianosis $(19 \%)$ dapat dilihat pada Tabel 1.

\section{DIAGNOSIS BANDING}

Diagnosis banding TP meliputi: acute coronary syndrome, acute respiratory distress syndrome, anemia, stenosis aorta, asma, fibrilasi atrial, kardiomiopati dilatasi, kardiomiopati restriktif, gagal jantung kongestif dengan edema paru, hantavirus cadiopulmonary syndrome, mitral stenosis, miokarditis, perikarditis, tamponade jantung, pneumonia, pneumotoraks, stenosis pulmonal, ARDS, syok kardiogenik, syok septik, superior vena cava syndrome, dan toxic shock syndrome. ${ }^{4,7}$

\section{LABORATORIUM}

\section{Pemeriksaan darah rutin}

Jumlah leukosit dapat meningkat. ${ }^{1,2,4}$ Hemoglobin dan hematokrit menurun pada anak penderita sickle cell anemia. ${ }^{2}$ Pemeriksaan pembekuan darah menunjukkan hasil yang normal pada penderita TP. ${ }^{4}$ Bila dicurigai adanya kelainan koagulasi familial atau didapat, dipertimbangkan untuk melakukan pemeriksaan seperti fibrinogen, aktivitas protein $C$, antigen protein $S$ bebas, aktivitas antitrombin III, analisis DNA untuk mutasi faktor $\mathrm{V}$ Leiden, uji lupus antikoagulan, dan antibodi antikardiolipin1.

Analisis gas darah (AGD)

Analisis gas darah arteri pada TP dapat normal. ${ }^{6,12}$ 
Temuan abnormal meliputi hipoksemia, hipokarbia, alkalosis respiratorik, dan bila curah jantung buruk dapat dijumpai asidosis metabolik. ${ }^{2}$ Pemeriksaan arterial-alveolar (A-a) gradien merupakan indikator yang lebih akurat daripada hipokarbia., Beberapa peneliti mengemukakan bahwa $A-a$ gradien yang normal dapat menyingkirkan TP. ${ }^{6}$

\section{D-dimer}

D-dimer merupakan derivat dari proses lisisnya trombus dan bukan berasal dari fibrinogen dalam sistem sirkulasi, sehingga pemeriksaan ini digunakan untuk tromboemboli vena. ${ }^{10}$ Pemeriksaan D-dimer dengan enzyme-linked immunosorbent assay (ELISA) mempunyai sensitivitas yang tinggi (85->98\%), 6 ,11 namun mempunyai spesifisitas yang rendah (40-50\%), ${ }^{2,10}$ serta mempunyai nilai positif palsu yang tinggi $(53 \%) .{ }^{11} \mathrm{D}$-dimer tuk

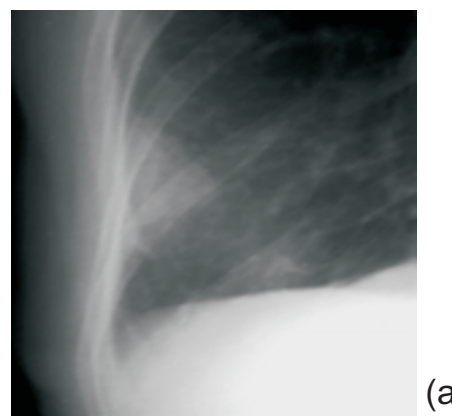

(a)

\section{Gambar 1(a) Gambaran Hamptom's Hump} Sumber: Jones dan Reid ${ }^{13}$

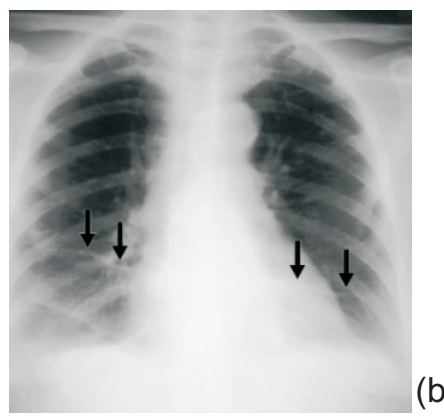

Gambar 1(b) Gambaran Fleischner Sumber: http://www.e-radiogra phy.net/radpath/p/pe2.htm

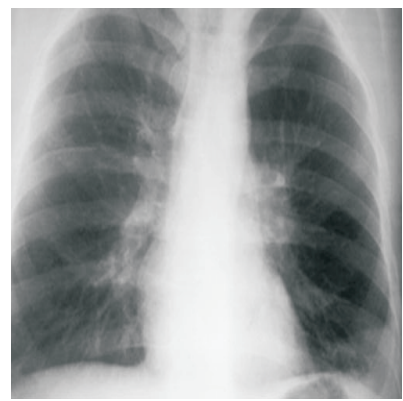

Gambar 2 Gambaran Westermark

Sumber: http://pathhsw5m54.ucsf.edu/ ${ }^{15}$ meningkat (cut-off point: $>500 \mathrm{ng} / \mathrm{mL}$ ) pada $90 \%$ pada penderita TP dewasa. ${ }^{2}$ Beberapa peneliti menyarankan pemeriksaan D-dimer harus dipertimbangkan bila dilakukan bersama ventilation/perfusion (V/Q) scan untuk diagnosis TP. ${ }^{6}$

\section{Foto toraks}

Temuan radiologi abnormal terdapat pada $84 \%$ penderita dengan TP. ${ }^{6}$ Perubahan foto toraks yang dapat ditemui pada TP meliput, atelektasis, efusi pleura, infiltrat pulmonal, dan elevasi hemidiafragma. ${ }^{4,6,8}$ Tanda klasik seperti Hamptom's hump (densitas pleural berbentuk baji di area infark paru), tanda Westermark (penurunan vaskularitas ditunjukkan dengan peningkatan densitas lusen di daerah perifer), dan tanda Fleischner (arteri pulmonalis berbentuk sosis) jarang ditemukan dan bukan prediktor yang baik untuk TP. ${ }^{2,6,8}$

\section{Lower limb venous compression ultrasonography}

Dengan memperkirakan bahwa TP disebabkan adanya trombi yang berasal dari vena dalam di kaki (sampai 90\%) dan biasanya bersifat asimtom, maka pemeriksaan ini mempunyai makna yang penting dalam mendeteksi DVT secara noninvasif. Pemeriksaan ini mempunyai nilai sensitivitas sebesar $30-50 \%$ dan spesifisitas $97 \% .{ }^{16}$ Hasil normal ditunjukkan dengan vena yang dapat ditekan secara mudah dan sempurna, sedangkan arteri pada otot resisten terhadap tekanan. Pada DVT didapatkan vena tidak dapat kolap secara sempurna ketika tekanan diberikan melalui probe ultrasonography (USG). Hasil yang negatif tidak menyingkirkan DVT, karena 2/3 penderita TP mempunyai lokasi DVT yang tidak dapat divisualisasi oleh USG. ${ }^{4}$

\section{Elektrokardiografi (EKG)}

Elektokardiografi dilakukan bila dicurigai adanya gangguan jantung. Perubahan yang terjadi pada TP tidak spesifik seperti, takikardia, perubahan gelombang ST-T (50\%), right bundle branch block (RBBB), right axis deviation (RAD), gelombang $T$ inversi dan $P$ pulmonal, namun gambaran EKG dapat normal pada $20-30 \%$ penderita TP.

\section{Ekokardiografi}

Transthoracic atau transesophageal echocardiography dapat memperlihatkan trombi emboli pada ruang jantung kanan (terutama atrium kanan) dan arteri pulmonalis sentral, serta memperlihatkan perubahan hemodinamik jantung kanan. ${ }^{3,8}$ Parameter tidak langsung seperti, dilatasi/disfungsi ventrikel kanan yang tidak dapat dijelaskan dan adanya regurgitasi trikuspid yang ditemukan pada pemeriksaan ini mempunyai nilai sensitivitas $50 \%$ dan spesifisitas $>90 \%$. Bersama-sama dengan pemeriksaan klinis dan hasil pemeriksaan noninvasif (seperti USG vena), pemeriksaan ini dapat digunakan untuk mendiagnosis TP pada penderita yang 
sangat berat, minimal sampai penderita tersebut dapat dilakukan pemeriksaan penunjang yang lain. ${ }^{8,11}$ Karena pemeriksaan ini menghasilkan visualisasi yang buruk dari arteri pulmonalis perifer, maka pemeriksaan ini tidak dijadikan standar diagnostik. ${ }^{8}$

\section{V/Q scan}

Pemeriksaan ini berdasarkan gambaran hambatan partikel radioaktif pada kapiler pulmonal. ${ }^{2}$ V/Q scan dilakukan dalam dua tahap, tahap pertama partikel albumin yang diberi label radioaktifa ${ }^{99 m}$ Technetium disuntikkan intravena dan kemudian dideteksi menggunakan kamera gama. Daerah dengan penurunan perfusi merupakan daerah dengan penurunan emisi radiasi. Pemeriksaan ventilasi dilakukan dengan menghirup xenon (Xe) radioaktif 133, kemudian hasil pemeriksaan ventilasi dibandingkan dengan perfusi. ${ }^{2,3,10,17}$ Diagnosis TP ditentukan bila terdapat daerah dengan ventilasi normal, namun terjadi penurunan perfusi. ${ }^{6}$ Hasil pemeriksaan dibagi dalam lima katagori, yaitu normal, very low probability, low probability, intermediate probability, dan high probability. ${ }^{6,3,12}$ High probability ditentukan bila ditemukan $\geq 2$ defek perfusi dengan normal ventilasi. ${ }^{2,4}$ Pada penelitian PIOPED, didapatkan $40 \%$ penderita TP dengan high probability V/Q scan, $40 \%$ intermediate probability dan $14 \%$ low probability, namun low probability tidak menyingkirkan diagnosis TP. ${ }^{6,18}$ Kecurigaan secara klinis yang tinggi terhadap TP dikombinasikan dengan temuan high probability V/Q scan mempunyai nilai prediksi positif: 88$96 \%$, sedangkan kecurigaan klinis yang rendah dengan low probability V/Q scan mempunyai nilai prediksi negatif: $88-96 \%{ }^{6}$

\section{Digital subtraction pulmonary angiography (DSPA)}

Angiografi merupakan pemeriksaan gold standard untuk mendiagnosis TP. ${ }^{12,14}$ Pemeriksaan ini bersifat invasif, dengan menempatkan kateter pada arteri pulmonalis. ${ }^{12}$ Zat kontras digunakan untuk mendapatkan gambaran arteri dan vena pulmonalis. ${ }^{14}$ Pemeriksaan ini dapat mendeteksi tromboemboli sebesar $1 \mathrm{~mm}$. Hasil positif didefinisikan sebagai defek pengisian intraluminal yang tampak lebih dari satu gambaran radiografi. ${ }^{2}$ Hasil positif memberi gambaran $100 \%$ bila memang terdapat obstruksi aliran darah arteri pulmonalis, sedangkan hasil negatif dapat memastikan sebesar $>90 \%$ untuk menyingkirkan diagnosis TP. ${ }^{4}$ Angka morbiditas angiografi berkisar $1-2 \%$ dan angka kematian $0,1-0,5 \%$, terutama pada penderita yang tidak stabil atau dengan penyakit kardiopulmonal yang berat. Komplikasi berupa perdarahan, ruptur arteri pulmonalis, dan henti jantung. Pemeriksaan intra-arterial DSPA lebih aman dan menghasilkan gambar yang baik dari intravena DSPA. ${ }^{6}$

\section{Pulmonary computed tomografi angiography (PCTA)}

Pada PCTA/multidetector helical (spiral) CT, zat kontras disuntikkan melalui pembuluh darah vena perifer (noninvasif). ${ }^{4,17}$ Pada pemeriksaan ini, TP disebut kronik jika terdapat gambaran: 1) trombus terletak eksentrik atau berdekatan dengan dinding pembuluh darah, 2) diameter arteri berkurang $>50 \%, 3$ ) adanya rekanalisasi di dalam trombus, dan 4) adanya arterial web. Gambaran akut jika terdapat trombus di tengah lumen atau terjadi oklusi pembuluh darah (vessel cut-off sign). Tromboemboli dapat dibagi atas sentral atau perifer tergantung dari lokasi atau cabang arteri yang terkena. Sensitivitas PCTA pada tromboemboli sentral adalah $100 \%,{ }^{5}$ sedangkan spesifisitasnya $78-100 \%,{ }^{10}$ namun untuk subsegmental sensitivitasnya $5-36 \%{ }^{5}$

\section{Magnetic resonance imaging (MRI)}

Seperti juga spiral CT, pada MRI trombi tampak sebagai defek pengisian pada arteri pulmonalis. ${ }^{12} \mathrm{MRI}$ sensitif untuk trombi yang terletak di proksimal tetapi tidak untuk yang di perifer. Untuk sentral tromboemboli sensitivitasnya $90 \%$ dan spesifisitas $80 \%$, sedangkan MR angiografi mempunyai sensitivitas $92-100 \%$ dan spesifisitas $62 \%$ untuk mendiagnosis TP. Keterbatasan pemeriksaan ini adalah mahal, tidak mudah didapatkan, sulit dilakukan pada penderita critically ill, sesak, dan mempunyai klaustrofobi. ${ }^{6}$

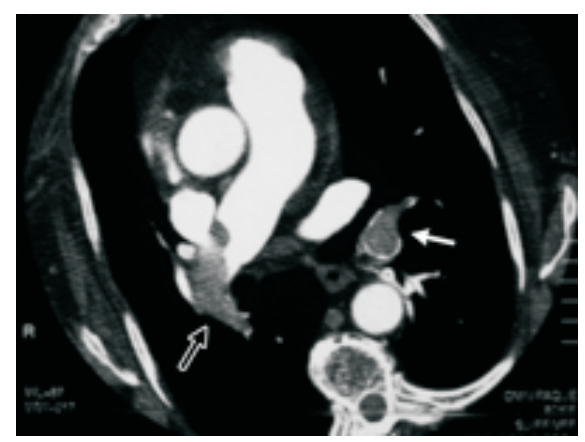

Gambar 3 Spiral CT scan (Memperlihatkan Defek Pengisian pada Arteri Pulmonalis) Sumber: Carman dan Deitcher ${ }^{10}$ 


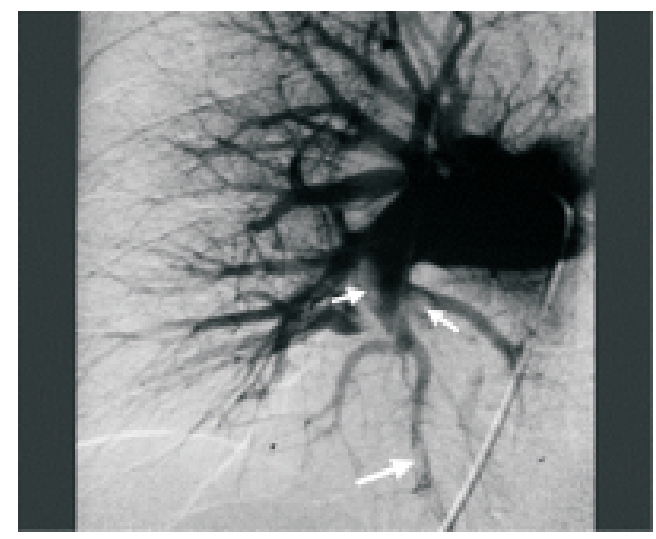

Gambar 4 Pulmonary Angiography (Memperlihatkan Defek Pengisian Intraluminal pada Arteri Segmental dan Subsegmantal Lobus Bawah)

Sumber: Carman dan Deitcher ${ }^{10}$

\section{DIAGNOSIS}

Diagnosis TP ditentukan dengan pemeriksaan klinis, adanya faktor risiko, pemeriksaan gas darah, foto toraks, EKG, dan pemeriksaan penunjang lain. ${ }^{15}$ Diagnosis TP didapatkan bila terdapat: ${ }^{11}$ 1) pulmonary angiography (PA): defek pengisian intraluminal, 2) Spiral CT: defek pengisian intraluminal pada arteri pulmonalis utama dan lobar, 3) V/Q scan: high probability scan dan moderate/high clinical probability, dan 4) Uji diagnostik untuk DVT: adanya DVT akut dengan V/Q scan atau spiral CT. Diagnosis TP dapat disingkirkan bila: ${ }^{11}$ 1) PA: normal, 2) Perfusion scan: normal, 3) D-dimer: normal dengan sensitivitas $\geq 98 \%$ dan spesifisitas tes $\geq$ $40 \%$, 4) D-dimer: normal dengan sensitivitas $\geq$ $85 \%$ dan spesifisitas $\geq 70 \%$ dan a) kecurigaan klinis yang rendah untuk TP, b) Fraksi alveolar dead space hasil normal, 5) Nondiagnostik (lowintermediate) V/Q scan/normal spiral CT, dan normal USG DAN a) Kecurigaan klinis yang rendah untuk TP, b) D-dimer: normal dengan sensitivitas $\geq 85 \%$ dan spesifisitas $\geq 70 \%$.

\section{TATA LAKSANA}

Penatalaksanaan dasar penderita TP adalah mendahulukan resusitasi. Penderita TP dengan gagal napas akut memerlukan intubasi endotrakeal dan ventilasi mekanik untuk meningkatkan pertukaran gas. Hemodinamik yang tidak stabil memerlukan terapi cairan dan zat inotropik, tetapi pemberian cairan yang berlebihan akan menimbulkan gagal jantung dari ventrikel kanan yang sudah mengalami kerusakan. Terdapat tiga pendekatan utama untuk terapi penderita TP yang telah stabil, yaitu antikoagulan, trombolisis, dan trombektomi dengan pembedahan. ${ }^{1}$ Terapi antikoagulan bertujuan untuk mencegah perluasan clot dan tromboemboli rekurens, serta menurunkan angka kematian. ${ }^{3,4,7}$

\section{Antikoagulan}

Heparin (unfractionated heparin/UFH)

Heparin bekerja meningkatkan aktivitas inhibisi dari antitrombin II pada faktor Xa dan inaktivasi trombin. Pemberian heparin intravena secara kontinu dengan loding dose 50-75 U/kg dilanjutkan 10-25 U/kg/jam. ${ }^{1}$ Pemberian heparin untuk mempertahankan activated partial thromboplastin time (aPTT) 1,5-2 kali nilai normal. ${ }^{1,9}$ Kontraindikasi pemberian heparin meliputi: perdarahan aktif, penyakit perdarahan, dan septik tromboemboli. ${ }^{9}$

\section{Low molecular weight heparin/LMWH}

Antikoagulan ini mempunyai efektivitas yang sama dengan UFH, mempunyai waktu paruh yang panjang sehingga dapat disuntikkan 1-2 kali sehari, dan hanya diekskresi melalui ginjal. ${ }^{1}$ Obat yang termasuk golongan ini adalah lovenox (enoxaparin) dengan dosis $1 \mathrm{mg} / \mathrm{kg}$ subkutan tiap 12 jam. ${ }^{4,7}$

\section{Warfarin (coumarin)}

Obat ini menekan faktor pembekuan yang tergantung vitamin $\mathrm{K}$, sebaiknya mulai diberikan 24-48 jam setelah terapi heparin diberikan, karena memerlukan waktu 5 hari untuk untuk mencapai efek maksimal. ${ }^{1}$ Dosis yang digunakan adalah 0,05-0,34 mg/kgBB/hari per oral. ${ }^{4,7}$

\section{Trombolitik}

Obat-obat golongan ini antara lain: urokinase, streptokinase, dan recombinant tissue plasminogen activator (rt-PA). Pemberian trombolitik ditujukan sebagai tambahan terapi heparin, terutama digunakan untuk penderita TP dengan ketidakstabilan hemodinamik, dan kontraindikasi pemberian obat ini pada penderita dengan perdarahan aktif, trauma serebrovaskular (terjadi $<2$ minggu), dan trauma. ${ }^{1}$ Dosis urokinase $4.400 \mathrm{U} / \mathrm{kgBB}$ iv selama 10 menit dilanjutkan dosis rumatan $2.000-4.400 \mathrm{U} / \mathrm{kgBB} / \mathrm{jam}$ selama 12-72 jam. Dosis streptokinase 3.500-4.000 $\mathrm{U} / \mathrm{kgBB}$ iv selama 30 menit dilanjutkan dosis 


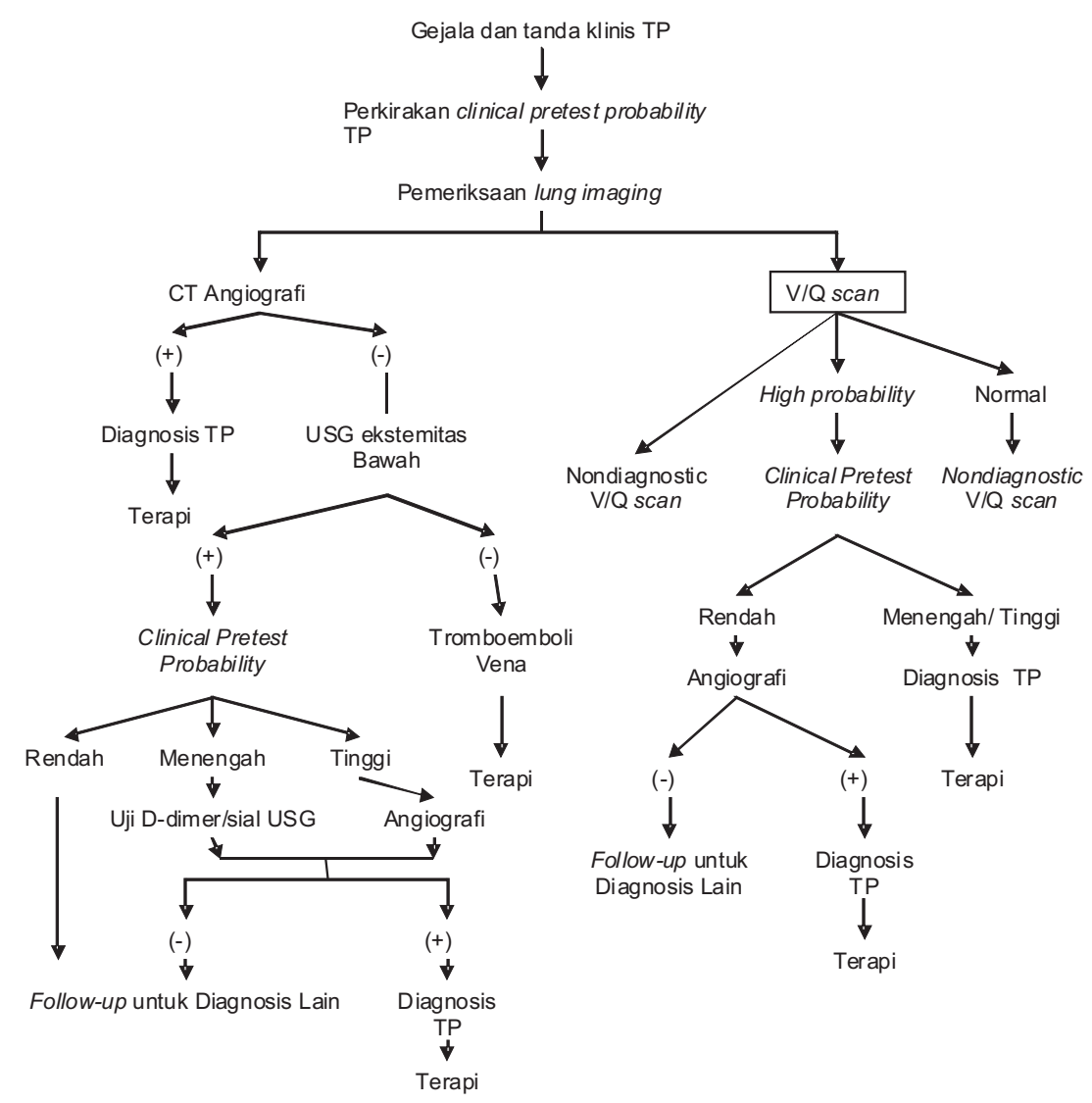

Gambar 5 Algoritma Diagnosis Tromboemboli Paru

Dikutip dari: Ramzi dan Leeper ${ }^{18}$

rumatan $1.000-1.500 \mathrm{U} / \mathrm{kgBB} / \mathrm{jam} \cdot{ }^{3,4,7}$ Dosis rt-PA $0,1 \mathrm{mg} / \mathrm{kgBB} / \mathrm{jam}$ selama $11 \mathrm{jam}$. Pemberian trombolitik pada neonatus tidak memberikan respons karena aktivitas fibrinogen inadekuat. ${ }^{3}$

\section{Trombolektomi operatif}

Tindakan ini sebaiknya dilakukan pada penderita TP yang mengalami gangguan hemodinamik menetap meskipun telah mendapat terapi antikoagulan. Tindakan ini dilakukan secara open thoracotomy dengan angka kematian yang tinggi. ${ }^{1}$

\section{PROGNOSIS}

Prognosis TP tergantung penyakit yang mendasarinya, diagnosis, serta terapi TP yang tepat. Dalam 5 hari terapi antikoagulan sebanyak 36\% defek pada scan paru menghilang, dalam 2 minggu terapi $52 \%$ defek menghilang, dan setelah 3 bulan terapi $73 \%$ defek menghilang. Pada umumnya penderita yang mendapat terapi antikoagulan tidak menimbulkan gejala sisa jangka panjang. Angka kematian penderita TP yang tidak terdiagnosis adalah $30 \%$. Berdasarkan PIOPED, angka kematian 1 tahun sebanyak $24 \%$ dan kematian terjadi karena penyakit jantung, EP rekurens, infeksi, serta kanker. Sekitar $17 \%$ penderita TP rekurens menderita DVT proksimal. ${ }^{7}$

\section{DAFTAR PUSTAKA}

1. Sloniewsky D, Green TP. Pulmonary hemorrhage, embolism, and infarction. Dalam: Behrman RE, Kliegman RM, Jenson HB, penyunting. Textbook of pediatrics. Edisi ke17. Philadelphia: Saunders Company; 2004. hlm. 1457-9.

2. Voughan DJ. Pulmonary infarction (diunduh 26 Juli 2005). Tersedia dari: http://emedicine.Pul monaryinfarction.html.

3. Donnerstein RL, Berg RA. Pulmonary embolism. Dalam: Taussig LM, Landau LL, penyunting. Pediatric respiratory medicine. St Louis: Mosby; 1999. hlm. 910-5.

4. Feled G, Handler JA. Pulmonary embolism. Dalam: Beeson MS, Talavera F, Setnik G, Halamka J, O'connor RE, penyunting (diunduh 31 Januari 2006). Tersedia dari: http://www. emedicine.com/EMERG/topic490.html.

5. Garg K. Acute pulmonary embolism. Dalam: Amorosa JK, Coombs GD, Stern EJ, Krasny RM, White CS, penyunting (diunduh 31 Januari 2006). Tersedia dari: http://www.emedicine .com/radio/topic582.html. 
6. Coluciello SA. Pulmonary embolism: etiology and clinical features (diunduh 28 Juli 2005). Tersedia dari: http://www.EMRtextbook.com.

7. Sharma S. Pulmonary embolism. Dalam: Tino G, Talavera F, Anders GT, Rice TD, penyunting (diunduh 1 Februari 2006). Tersedia dari: http://www.emedicine.com/med/topic1958.ht $\mathrm{ml}$.

8. Palmer SM, Tapson VF. New approaches to the diagnostic of pulmonary embolism. Hospital Physician. 1999:23-32.

9. Pulmonary embolism. The merck manual of diagnosis and therapy (diunduh 31 Januari 2006). Tersedia dari: http://www.merck.com /mrkshared/mmanual/section6/chapter72/72a .jsp.

10. Carman TL, Deitcher SR. Advances in diagnosing and excluding pulmonary embolism: spiral CT scan and D-dimer measurement. Cleaveland Clin J Med. 2002;69(9):721-9.

11. Kearon C. Diagnosis of pulmonary embolism. CMAJ. 2003;168(2):183-94.

12. Kohli A, Rajput D, Gomes M, Desai S. Imaging of pulmonary thromboembolism. Ind J Radiol Imag. 2002;12(2):207-12.

13. Jones MR, Reid JH. Emergency chest radiology: thoracic aortic disease and pulmonary. Imaging. 2006;18:122-38.

14. Pulmonary embolism (diunduh 10 Desember 2008). Tersedia dari: http://www.eradiography.net/radpath/p/pe2.htm.

15. Radiographic signs of thromboembolism (diunduh 10 Desember 2008). Tersedia dari: http://images.google.co.id/imgres?imgurl=http ://pathhsw5m54.ucsf.edu/cts/unknown16/ima ges/figure6.jpg\&imgrefurl=http://pathhsw5m5 4.ucsf.edu/cts/unknown16/radiographs.html\& usg $=$ XuBvXzKHb4BlzWZIDssZXROgwNU= $\& h=3 \overline{75} \& \mathrm{w}=500 \& s z=19 \& \mathrm{hl}=\mathrm{id} \& \mathrm{start}=7 \& \mathrm{tbnid}$ $=x 3$ YvsIT5JvNLzM:\&tbnh=98\&tbnw=130\&pre v=/images \%3Fq\%3Dwestermark\%2527s\%2B sign $\% 26 g b v \% 3 \mathrm{D} 2 \% 26 \mathrm{hl} \% 3 \mathrm{Did} \% 26 \mathrm{sa} \% 3 \mathrm{DG}$,

16. Perrier A. Noninvasive diagnosis of pulmonary embolism (diunduh 2 Februari 2006). Tersedia dari: http://www.hosppract.com/issues/ 1998/ 09/ ceperr.html.

.17. Charles HW. Pulmonary angiography. Dalam: Watkinson A, Coombs BD, Hartnell GG, Krasny RM, White CS, penyunting (diunduh 28 Juli 2005). Tersedia dari: http://emedicine.Pulmo naryangiography.htm.

18. Rami DW, Leeper KV. DVT and pulmonary embolism part I: diagnosis (diunduh 1 Februari 2006). Am Fam Physician. 2004:69:282936.Tersedia dari: http://www.aafp.org/afp/ 20040615/2829.html 